NBER WORKING PAPERS SERIES

HUMAN CAPITAL ACCUMULATION AND INCOME DISTRIBUTION

Raquel Fernandez

Richard Rogerson

Working Paper No. 3994

NATIONAL BUREAU OF ECONOMIC RESEARCH

1050 Massachusetts Averue

Cambridge, MA 02138

February 1992

This research was conducted in part while R. Fernandez was a visiting fellow at the Hoover Institution. We thank seminar participants at Brown, Haryard, and the NBER Summer Institute for comments. An earlier version of this paper circulated under the title "On the Political Economy of Educational Subsidies." Any opinions expressed are those of the authors and not those of the National Bureau of Economic Research. 
NBER Working Paper \#3994

February 1992

\title{
HUMAN CAPITAL ACCUMULATION AND INCOME DISTRIBUTION
}

\begin{abstract}
This paper analyzes the extent to which education will be subsidized when the subsidy rate is determined by majority voting. The analysis takes place in a framework where education is a discrete decision and all individuals would like to obtain an education because of its effect on future eamings. Individuals differ in their initial income levels. The non-existence of credit markets implies that initial income is a determinant of who actually obtains an education. We consider the outcome of a process in which income is taxed to provide subsidies for education, and taxes are chosen by majority voling. We characterize the outcome as a function of both the level and the distribution of income in the economy. In particular we derive conditions under which middle income individuais ally themselves with upper income individuals at the expense of lower income individuals, and vice versa The analysis determines the relationship between human capital accumulation and distribution of income.
\end{abstract}

Raquel Fermandez

Department of Economics

Boston University

Boston, MA 02215

and NBER
Richard Rogerson

Department of Economics

University of Minnesota

Mirneapolis, MN 55455

and NBER 


\section{Int roduct ton}

Socleties intervene in the area of education in a varlety of ways. That they should choose to do so 1 s perhaps not surprising: plausible economic Justifleations for intervention are plentlful and range from the existence of market imperfections of various sorts (especially 1mperfect capltal markets), to externalities from education both static and dynamic, to publle goods arguments. The factors that determine the extent and the forms that these interventions take seem far less obvious, however, Heterogenelty among Individuals, whether in terms of Income, ablity or locality, tends to generate conflicting preferences as to the kind of pollcles that are most desirable. Thus, there is reason to suspect that there may be substantial disagreement in the cholce of, for example, the optimal degree of subsidization of education, the quality of education, the rules that should determine an individual's eligibility for particular subsidles le.g. guaranteed student loans, scholarshlps, or financlal ald), or the desirability of barrlers to entry such as entrance examlnations or enrollment restrictions. In the absence of a social planner that chooses policles to maximize a well-defined welfare function, an analysis 19 required to understand how heterogenelty and the political system interact to generate different features of the educational system. 1

The focus of thls paper is relatively narrow. We seek to examine how Income heterogeneity in particular may affect the political feasibility of

1 There is a growlng literature that examl nes political forces as a determinant of economic outcones. Early examples are Schumpeter (1947), Downs (1957), and Buchaman and Tullock (1962). More recent studies 1nclude Heltzer and Rlchard (1981), Alesina (1987), Persson and Tabellini (1990), and Fernandez and Rodrik $(1991)$. 
educational subsidies. To do so we deliberately simplify our framework, both econonic and political, so as to highlight some of the fundamental tensions at work as a consequence of Income heterogeneity and a system of majority rule.

At the econonic level, Individuals are assumed to be ex ante Identical in every respect except for their initial 1ncone. Education is a discrete investment good and capital markets are imperfect. An individual's cost of acquirling an education is uniformly subsidized through a proportional income tax Ievled on the general public. The subsidy. however, is avatlable only to Ehose Individuals who choose to acquire an education. Since we assume that all Individuals would benefit from obtaining an education, an individual's lncome and the subsidized cost of education are the sole determinants of whether they w111 do so.

At the political leveI, we have chosen the equilibrium concept of majority rule, thus allocating each individual equal welght in determining the outcome. The tax rate, and hence the extent to whlch education is subsidized, Is voted on directly and 15 therefore endogenously deternined.

We derlve the majorlty voting equilibrlum of the econony. In equilibrium the degree of subsidization of education depends both on the wealth of the economy and on 1 ts distribution. Specifically, it depends on the economy's average income relative to the cost of education and or each 1ccome group's abllity to extract revenue from another. The latter, we show, is determined by the relative income levels, by the allocation of the population among the different income groups, and by whether particular groups can afford to obtain ar. education at a zero subsidy.

Interpreting the results requires understanding how alliances are generated anong income groups for different costs of education and different 
Income distributions. ${ }^{2}$ As will be shown, the middle class is often the plvotal group. There are cases, however, in which the poor and rich ally agalnst the middle clase, but these are relatively few for reasons that will be made clear in the paper. Loosely speaking, we find that the equilibrium tax rate tends to 1ncrease as an economy becomes wealthler as long as subsidization still plays a meaningful cole (1.e. as long as some individuals st1ll need a non-zero subsidy to afford an education). Interestingly, however, not all Individuals necessar1ly prosper as soclety's wealth increases relative to the cost of education. The welfare of a poor individual conditional on a constant income, for example, is not a monotonically Increasing function of soclety's average wealth. While in a poor society the equllibrium tax is zero. In a mediumly well-off one (in a sense that will be made precise in the paper) the tax rate is set at a level that ensures the maximum degree of exploitation of the poor, 1.e. a tax rate which just prevents them from obtaining an education. In a richer economy with an equilibrium tax rate of one, they are best off. This contrasts in an interesting way with the results of Stiglitz (1974) who argued, for several varlants of his model, that majority voting favors the prefences of the poor If the median income is less than the mean. This need not be the case in our framework.

Our paper is not, of course, the first to examine the determinants of af economy's degree of subsidization of education. Creedy and Francois (1990) examine an economy in which the growth rate is an increasing function of the

2 Several authors have commented on and documented the tendency for the system of hlgher education financing to $1 \mathrm{mply}$ a transfer from the $r 1 \mathrm{ch}$ and the poor to the middle class (see e.g. Hansen and Weisbrod (1969), Hansen (1971), and Peltzman (1974)). 
number of people educated. The authors assume that individuals are able to share in the benefits from growth regardless of whether they receive an education. Given 1ncome heterogeneity and complete capital markets they show that, for a particular income distribution, majority rule results in the subsidization of education despite the fact thet the median voter is uneducatad. G.E. Johnson (1984) provides a different motivation for why Individuals who do not directly benefit from education may nonetheless wish to subsidize education. In this economy heterogeneity is in the level of skills possessed by a worker (hlgh, medlum, or low), rather than in initial incone. Sufficlent complementarity in the production function can provide lowrskilled workers with an incentlve to subsidize education for medium-skilled workers (which transforms the latter into high-skilled workers) although low-skilled workers themselves w11 not obtain an education. ${ }^{3}$ Perott's (1990) framework is perhaps the most simllar to ours: capltal markets are 1mperfect, education Is the sole discrete cholce varieble, and majority vote determines the value of the tax rate. Taxation works differently than in our model. however. Tax revenue is redigtributed independently of an individual's schooling decision, and there 15 also redistribution of eecond-period earnings. Second-period redistribution may incince the poor to subsidize education, even if oniy the rich Individuals get educated.

The main feature that distinguishes our work from those discussed above is our assumption that Individuals are unable to share in others' galns from

3 In a rather different vein, K.E. Lommerud (1989) discusses the role of relative income concerns as an additional justification for the provision of educational subsidles and J.R. Lott (1990) suggests that the fublic provision of schooling is undertaken by the state since it lowers the opposition to wealth transfers by indoctrinating students with the "correct" set of beliefs. 
education. It is not that we consider such factors as the overall beneflts from growth (Creedy and Francolg), complementarlties in production (Johnson), and increaged tax revenues for redistribution (Peroti1), to be unimportant motivators for society"s wllingness to subsldize education. Father, we wish to understand, in the absence of such consideratlons, whlch groups would form an alliance favorling subsidization of education and to what degree. Who benefits and at whose expense (If anyone's)? How does the degree of subsidization relate to the distribution of Income among different groups? How is it affected by the slze of these groups? How does it relate to the cost of education? In what way does the overall wealth of an economy play a role? These are sone of the questions that we are able to examine in our model without the additional Impetus favoring the subsidization of education. that would be introduced by any of the other factors previously mentioned. The fundamental tensions that we ldentify in this asic model are likely to be present in models that incorporate additional factors in their analyses.

\section{The Model}

In order to study in as stark and simple a framework as possible some of the Interactions between income distribution, the political systen and education, we choose to abstract away from considerations that may be generated by other factors such as income smoothing concerns, intergenerational bequest motivations, heterogenelty in preferences and ablilttes among individuals, etc.. He place emphasis instead on the affordability of education in an economy in whlch each Individual would 
benefit by acquiring an education. ${ }^{4}$

The economy consists of a continuum of two-perlod lived agents with total mass equal to one. There is a sligle consumption good and Individuals have a linear utlifty function defined over flrst and second-perlod consumption. There is no dlscounting. The agents belong to one of three groups, differentlated by their Initial income (equivalently, endomment of the consumption good) which is assumed to take on the values $y_{1}, y_{2}$, or $y_{3}{ }^{5}$ He assume that $y_{1}>y_{2}>y_{3}$, and wlll often refer to the three groups of agents ag rich, middle class, and poor respectively. The fraction of agents in group I is wTitten as $\lambda_{1}$.

In the flrst perlod of her $11 \mathrm{fe}$, each agent decides whether to obtuin an education. The cholce is zero-one and the cost of obtaining an education (w1th zero subaldy) is E. ${ }^{6}$ The benefit from education for an individual from group 1 is that second-period income equals $f\left(y_{1}\right)$. By contrast, an indlvidual who does nat obtaln an education in the first perfod receives a second-period income equal to $y_{1}$. We assume that $f\left(y_{1}\right)-E>y_{1}$ for all 1 . This ensures that all Individuals would like to obtaln an education.

The market structure that we consider, however, does not necessarily permit all individuals to obtain an education. Indlviduals are assumed not to

${ }^{4}$ Af fordability is not generally an 1ssue at the prlmary and secondary level of education. Thus, this model is perhaps best viewed as concerning the stibsldization of higher education.

5 He have chosen to assume only three types of agents slnce it allows for closed form solutions and hlghlights the nature of the tensions anong income groups.

${ }^{6}$ We have deliberately chosen to model the acquisition of education as a discrete cholce. In terms of our results, what matters is that some individuals should find themselves at a corner with respect to their cholce to invest in education. 
have access to credit markets and hence cannot borrow against future earnings to finance expenditures on education when young. ${ }^{7}$ It follows that period-one income will be a determinent of whether an individual obtalns an education. 8

A second factor that determines whether a given individual will recelve an education is the extent to which education is subsidized. In owr model education is (endogenously) a partially publicly provided private good that is subsidized solely via a proportional tex $\theta$ on period-one income. ${ }^{9}$ The proceeds from taxation are digtributed equally among all individuals that recelve an education.

We study equilibria for the above economy in which the choice of the tax rate $\theta$ is endogenously determined by majority rule. Thus, by voting upon a tax rate Individuals are simultareously deciding two things: 1) the height of the "entry barrier" to education, 1.e. the Identity of the individuals who can afford to get educated, and 2$)$ the degree to whlch educated Individuals can extract revenue from those individuals who are not educated (and hence who do not receive a benefit from taxation). Of course, these two are simultaneously determined and thus cannot be chosen independently of one another. The barrler to entry aspect is central to our analysis and, in particular,

\footnotetext{
7 Pecent empirical work by Behrmen, Pollak and Taubman (1989) finds evidence for the existence of credit constralnts in the context of education. We do not model here the particular microfoundations underlying this market fallure. This would merely complicate the model and $1 \mathrm{ts}$ exact features are not critical. The essential feature is not that individuals cannot borrow at all, but rather that access to credit markets is such that initial income remains a determinant $1 \mathrm{n}$ an individual's decision to acquire education.

${ }^{8}$ Dur specification implies that individuals may spend all their income on education. This could be generalized to include expenditures on other goods. What matters is that for some individuals income is a binding constraint on the1r purchase of education.

Thus we are implicltly constralning our system from resorting to iump-sum taxation and other schemes.
} 
distingutshes it from the bulk of voting models on education in which tax revenue is redistributed independently of an individual's education decision (e.g. Stiglitz (1974) and Perott1 (1990)).

Before proceeding to the equilibrium analysis it is useful to analyze the relationship between values of the tax rate, individual actions and utilities. Consider flrst the relationshlp between the tax rate, the government subsidy to education and the fraction of the population that receives an education. W1 th a tax rate equal to $\theta$, tax revenueg $T(\theta)$ are given by:

$$
T(\theta)=\theta \Sigma \lambda_{1} y_{1}=\theta \mu
$$

where $\mu$ is average income (whlch also equals total income since the mass of agents is one). If $N(\theta)$ represents the mass of agents who receive an education, then the per person subsidy $s(\theta)$ is given by

$$
g(\theta)=\theta \mu / N(\theta) \text {. }
$$

The difficulty with these expressiong is that $N$ and $s$ are jointly determined by $\theta$. A simple procedure, however, allows us to determine the values of $s$ and N that are mutually consistent.

Let $p_{1}(\theta)$ be the fraction of individuals of type 1 that recetve an education as a function of $\theta$. For a glven value of $s(\theta)$, an Individual of type $i$ can obtaln an education if $(1-\theta) y_{1}-E+s(\theta) \geq 0$. Cleariy, if an 1ndividual from group 1 can afford to be educated then so can ald individuals from group $J$ for all $\mathrm{J}<1$. Consider the following expression for any flxed value of $\theta$ :

$$
\left.(1-\theta) y_{j}-E+\theta \mu /\left(\sum_{1<j}\right)+v \lambda_{j}\right)
$$

First, set $j=1$ and $v=1$. If expression ( 3 ) is nonnegat 1 ve, then $p_{1}(\theta)=1$. Otherulse, at the tax rate of $\theta 1 \mathrm{t}$ is not possible for all of group one to be educated and $\rho_{1}(\theta)$ is that value of $v$ that sets (3) equal to zero. In this 
case $\rho_{2}(\theta)$ and $\rho_{3}(\theta)$ are equal to zero. If $\rho_{1}(\theta)=1$, this procedure 15 repeated for $j=2$, If $\rho_{2}(\theta)=1$, then it is repeated for $j=3$. This determines the values of $p_{1}(\theta)$ for any value of $\theta$. Whenever $0<p_{1}(\theta)<1$, we assume that a fraction $p_{1}(\theta)$ of agents from group 1 is randomly selected to obtain an education and that the remaining fraction $1-p_{1}(\theta)$ does not.

Having determined the values of the $\rho_{i}{ }^{\prime} s$, it is possible to express the expected utilities of each of the three groups as a function of the tax rate $\theta:$

$$
E U_{1}(\theta)=(1-\theta) y_{1}+p_{1}(\theta)\left[s(\theta)-E+f\left(y_{1}\right)\right]+\left(1-\rho_{1}(\theta)\right) y_{1} .
$$

since agents in this economy vote on the value of the tax rate to be 1nstituted, it is essential to understand how their respective utilites are affected by different values of $\theta$. A few prellminary results are belpful. First note that each of the functions $p_{1}(\theta)$ is non-decreasing in $\theta$. Second, and following directly from the algorithm outlined above, if $0<\rho_{1}(\theta)<1$ the following relationship holds:

$$
E-s(\theta)=(1-\theta) y_{1} \text {. }
$$

Some additional notation facilitates the characterization of the EU,"s. Let $\hat{\theta}_{2}$ be the maximum value of $\theta$ in $[0,1]$ for whlch $p_{2}(\theta)$ is equal to zero or, this value falling to exist. equal to $0 . \hat{\theta}_{2} 1 s$, therefore, the value of $\theta$ at which for any strictly positive increase in the tax rate it becomes possible for some Individuals of type two to obtain an education. Clearly, if $y_{2} z E$ then $\hat{\theta}_{2}$ equels zero. $\hat{\theta}_{3}$ Is defined analogously. Lastiy. define $\bar{\theta}_{1}$ to be the smallest value of $\theta$ for which $p_{1}(\theta)=1$, whenever such a number exists in the unit interval.

The following proposition characterizes the expected utilities for each type of agent. 
Proposition 1: $E U_{1}(0)$ is continuous and $\Sigma U_{1}(0)<E U_{1}\left(\bar{\theta}_{1}\right)$ for $\bar{\theta}_{1} E(0,1]$ and for all 1. Furthermore:

(1) $\mathrm{EV}_{1}(\theta)$ is tncreasing and concave on $\left[0, \vec{\theta}_{1}\right]$. 11nearly increasing on $\left[\bar{\theta}_{1}, \hat{\theta}_{2}\right]$ with marginal ut111ty of $\left[\mu / \lambda_{1}\right]-y_{1}, 1$ nearly decreasing on $\left[\hat{\theta}_{2}, \bar{\theta}_{2}\right]$ with marginal ut1lity $\mathrm{y}_{2}-\mathrm{y}_{1}$, linear on $\left[\bar{\theta}_{2}, \hat{\theta}_{3}\right]$ with marginal utility of $\left[\mu /\left(\lambda_{1}+\lambda_{2}\right)\right]-y_{1}$, linearly decreasing on $\left[\hat{\theta}_{3}, \bar{\theta}_{3}\right]$ with marginal utility $y_{3}-y_{1}$, and 1 inearly decreasing on $\left[\bar{\theta}_{3}, 1\right]$ with marginal utility $\mu-y_{1}$,

(11) $\mathrm{EU}_{2}(\theta)$ is linearly decreasing on $\left[0, \hat{\theta}_{2}\right]$ with marglnal utility of $-y_{2}$, Increasing and concave on $\left[\hat{\theta}_{2}, \bar{\theta}_{2}\right]$, 11 nearly 1ncreasing on $\left[\bar{\theta}_{2}, \hat{\theta}_{3}\right]$ with marginal ut1l1ty of $\left(\mu /\left(\lambda_{1}+\lambda_{2}\right]\right)-y_{2}$, linearly decreasing on $\left[\hat{\theta}_{3}, \bar{\theta}_{3}\right]$ with marginal ut111ty of $y_{3}-y_{2}$, and llnear on $\left[\bar{\theta}_{3}, 1\right]$ with a marginal utility of $\mu-\mathrm{y}_{2}$

(111) $\mathrm{EU}_{3}(\theta)$ is decreasing on $\left[0, \hat{\theta}_{3}\right]$ with marginal utility of $-\mathrm{y}_{3}$. increasing and concave on $\left[\hat{\theta}_{3}, \bar{\theta}_{3}\right]$, and linearly increasing on $\left[\bar{\theta}_{3}, 1\right]$ with marginal ut111ty of $\mu-y_{3}$.

Proof: Continulty of the EU,'s fallows directly fram the fact that the $\rho_{1}(\theta)^{\prime} \mathrm{s}$ are continuous. At $\bar{\theta}_{1}, E U_{1}=f\left(y_{1}\right)$. At $\theta=0, E U_{1}=2 y_{1}$. Given $f\left(y_{1}\right)-E$, $y_{1}$ and $y_{1}<E$ (1.e. $\left.\bar{\theta}_{1}>0\right)$ it follows that $f\left(y_{1}\right)>2 y_{1}$ and hence that $\mathrm{EU}_{1}(0)<\mathrm{EU}_{1}\left(\bar{\theta}_{1}\right)$ for $\bar{\theta}_{1} \mathrm{e}(0,1]$.

He prove (1); the remalning statements can be demonstrated similarly.

On $\left[0, \bar{\theta}_{1}\right]$, EU, $(\theta)$ ig given by $\operatorname{EU}_{1}(\theta)=\rho_{1}(\theta)\left[f\left(y_{1}\right)\right]+\left(1-p_{1}(\theta)\right]\left[(1-\theta) y_{1}+y_{1}\right]$ where $\rho_{1}(\theta)=\theta \mu /\left[\lambda_{1}\left(E-(1-\theta) y_{1}\right)\right]$. Note that $E U_{1}\left(\bar{\theta}_{1}\right)>E U_{1}(\theta)$ for all $\theta E\left[0, \bar{\theta}_{1}\right)$. Calculation ylelds $d E U_{1} /\left.d \theta\right|_{\theta=0}=\left[\mu\left(f\left(y_{1}\right)-2 y_{1}\right)-\lambda_{1} y_{1}\left(E-y_{1}\right)\right] /\left(\left(E-y_{1}\right) \lambda_{1}\right)$ which is positive since $f\left(y_{1}\right)>E+y_{1}>2 y_{1}$ (if $\bar{\theta}_{1}>0$ ) and $\mu>\lambda_{1} y_{1}$. Furthermore, $d^{2} E U_{1}(\theta) / d \theta^{2}=-2 \mu\left(E-y_{1}\right) y_{1}\left[f\left(y_{1}\right)-y_{1}-E\right] /\left[E-(1-\theta) y_{1}\right]^{3} \lambda_{1}<0$. since $E U_{1} 1 s$ increasing at zero, is concave throughout, and $\mathrm{EU}_{1}\left(\bar{\theta}_{1}\right)>\mathrm{EU}_{1}(\theta)$ for all $\theta \in$ 
$\left[0, \bar{\theta}_{1}\right)$, It follows that $\mathrm{EU}_{1}$ is increasing on the interval $\left(0, \bar{\theta}_{1}\right)$. On the Interval $\left[\bar{\theta}_{1}, \hat{\theta}_{2}\right], \mathrm{EU}_{1}$ 1s given by $\mathrm{EU}_{1}(\theta)=(1-\theta) y_{1}-E+\left(\mu \theta / \lambda_{1}\right)+f\left(y_{1}\right)$. Differentiation gives; $\quad \mathrm{dEU}_{1} / \mathrm{d} \theta=-\mathrm{y}_{1}+\mu / \lambda_{1}>0$. On the interval $\left[\hat{\theta}_{2}, \bar{\theta}_{2}\right]$, $\mathrm{EU}_{1}(\theta) 1 \theta$ given by $\mathrm{EU}_{1}(\theta)=(1-\theta) \mathrm{y}_{1}-(1-\theta) \mathrm{y}_{2}+f\left(y_{1}\right)$, since for $0<p_{2}(\theta)<1$. $E(\theta)=E-(1-\theta) y_{2}$. Differentiation gives $d E u_{1} / d \theta=y_{2}-y_{1}<0$. On the interval $\left[\bar{\theta}_{2}, \hat{\theta}_{3}\right], \mathrm{EU}_{1}$ is glven by EU $(\theta)=(1-\theta) \mathrm{y}_{1}-E+\left(\mu \theta /\left(\lambda_{1}+\lambda_{2}\right)\right)+f\left(\mathrm{y}_{1}\right)$. Differentiation gives $d E U_{1} / d \theta=-y_{1}+\mu /\left(\lambda_{1}+\lambda_{2}\right)$. Marglnal utility in this reglon is positive if $y_{1}<\mu /\left(\lambda_{1}+\lambda_{2}\right)$ and negative if the reverse inequality

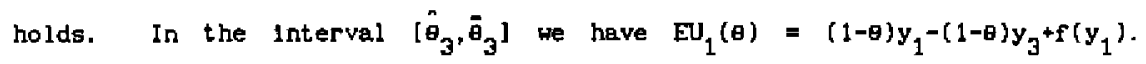

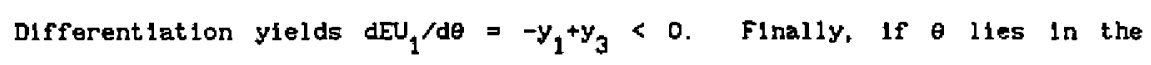
1nterval $\left[\bar{\theta}_{3}, 1\right]$. EU 1 is glven by $\mathrm{EU}_{1}(\theta)=(1-\theta) y_{1}-E+\mu \theta$. Differentiation gives $d E U_{1} / d \theta=-y_{1}+\mu$. This is negat Ive since $\mu$ is stmply the average of the $y_{1}^{\prime}$ s. This completes the proof of (1). Parts (11) and (111) are demonstrated similarly. ||

F1gure 1 depicts $E U_{1}$ as a function of $\theta$ for a particular set of parameter values.

\section{Majorlty Yoting Equilibrium}

The equilibrium is determined by majority voting on tax rates. He assume that Indlviduals vote sincerely.

Definition: An equllibrlum is a tax rate $\theta^{*}, 0 \leq \theta^{*} \leq 1$ such that for all $\theta^{\prime} c[0,1]$, the mass of agents $\mathrm{wlth}_{\mathrm{EU}}\left(\theta^{\prime \prime}\right) \geq \mathrm{EU}_{1}\left(\theta^{\prime}\right)$ 1 $\mathrm{s}$ strictly greater then 5.

Generically, each of the $\mathrm{EU}_{1}^{\prime} \mathrm{g}$ has a unique maximlzer on $[0,1]$. The discussion that follows assumes that the maximizers are unlque, although the case where unlqueness does not obtain is easlly handled. Denote the maximizer 
for group 1 by $\ddot{\theta}_{1}$. Note that uniqueness does not imply that individual preferences are single peaked; this is generically not true in this model (e.g. see Figure 1). Thus it is not possible to simply invoke the preferred tax rate of the medlan voter as the equllibrium tax rate.

As a flrst step in the characterization, note that $\tilde{\theta}_{1}$ necessarily corresponds to a local maximum of $\mathrm{EU}_{1}(\theta)$, and hence Proposttion 1 can be used to restrict the set of possible values of $\tilde{\theta}_{1}$. The possible values for $\tilde{\theta}_{1}$ are $\left\{\hat{\theta}_{2}, \hat{\theta}_{3}\right\}$, for $\tilde{\theta}_{2}$ are $\left\{0, \hat{\theta}_{3}, 1\right\}$, and for $\tilde{\theta}_{3}$ are $\{0,1\}$. For all groups $E U_{1}\left(\bar{\theta}_{1}\right)$ ? $\mathrm{EU}_{1}(0)$ (for $\bar{\theta}_{1} \mathrm{e}(0,11$ ), so zero can be a global maximum for an Indivicual of group 1 only if $1 \mathrm{t}$ is not feasible for all individuals in that group to obtaln an education at any tax rate. Also, it is possible for a tax rate of one to be a global maximun for group one, but only if $\hat{\theta}_{3}=1$. 1.e. only if there is no tax rate at which any individual of group three can obtaln an education.

The following proposition helps establish which value is taken by $\tilde{\theta}_{1}$ Proposition 2: Assume $y_{2}<E$. Then $E_{1}(0)>E_{1}\left(\bar{\theta}_{2}\right)$ if and only if $y_{1}>E$ and $\mu\left(\lambda_{1}+\lambda_{2}\right)<y_{1}$

Proof: If $\mathrm{E}>\mathrm{y}_{1}$ then $E U_{1}(\theta)>E U_{1}(0)$ for $0<\theta \leq 1$. If $E \leq y_{1}$ then $E U_{1}(0)=f\left(y_{1}\right)+y_{1}-E$, and $\mathrm{EU}_{1}\left(\bar{\theta}_{2}\right)=f\left(y_{1}\right)+\left(1-\bar{\theta}_{2}\right) y_{1}+\bar{\theta}_{2} \mu /\left(\lambda_{1}+\lambda_{2}\right)-E_{\text {. }}$ Hence $\mathrm{EU}_{1}(0)-\mathrm{EU}_{1}\left(\bar{\theta}_{2}\right)=$ $\left.\bar{\theta}_{2}\left[y_{1}-\mu /\left(\lambda_{1}+\lambda_{2}\right)\right]\right\}$ a 0 as $y_{1} \leq \mu /\left(\lambda_{1}+\lambda_{2}\right) \cdot \mid$

Note that the condition above is identical to the one that determines whether $\mathrm{EU}_{1}(\theta)$ is increasing on the interval $\left[\bar{\theta}_{2}, \hat{\theta}_{3}\right]$. The intuition underlying the proposition is easily understood. The net subsidy obtained by Individuals in group one for a given $\theta$ is $\theta\left[(\mu / N(\theta))-y_{1}\right]$. At $\bar{\theta}_{2}, N\left(\bar{\theta}_{2}\right)=\lambda_{1}+\lambda_{2}$. Hence, for $\theta \subset\left[\bar{\theta}_{2}, \dot{\theta}_{3}\right]$, the net subsidy w11l either monotonically increase or decrease depending upon whether $\mu /\left(\lambda_{1}+\lambda_{2}\right]{ }_{<}^{>} y_{1}$. The net subsidy at $\theta=0$ is 0 . Thus, the sole determ!nant of whether $E u_{1}(0)$ is greater than $E u_{1}\left(\bar{\theta}_{2}\right]$ [given 
$\left.y_{1}>E\right)$ is 11 kew 1 se whether the net oubstdy at $\bar{\theta}_{2}$ 1s positive or negative, $1 . e$. the same condition as before. A necessary condition, therefore, for $\tilde{\theta}_{1}$ to equal $\hat{\theta}_{3}$ rather than $\hat{\theta}_{2}$ is $\mu\left(\lambda_{1}+\lambda_{2}\right)>y_{1}$.

There is one case for whlch the equllibrium is immedlate. If any $\lambda_{1}$ is at least as great as .5 , then this group's $\tilde{\theta}_{1}$ is clearly a majorlty voting equilibrium. The following analysis considers the case where $\lambda_{1}<.5$ for each 1. Thus, the sum of any two of the $\lambda_{1}$ 's exceeds .5.

For a tax rate $\theta^{*}$ to be a majority voting equllibrium it must win agalnst all alternatives, and, in particular, against all local alternatives. This observation leads to the following result:

Theorem 1: If $\theta$ is a majority voting equilibrium then at least one of the $\mathrm{EU}_{1}$ 's has a local maximum at $\theta$.

Proof: Assume that no group has a local maximum at $\theta^{*}$. If $\theta$ "equals zero, $E U_{1}(\theta)$ must be uphard sloping at 0 for all 1 . But then there exists some $\theta$, 0 which all three groups prefer to 0 . If $\theta *$ equals one, $\mathrm{EU}_{1}(\theta)$ must be decreasing for all 1 as $\theta$ approacheg 1 . Again, there 18 some $\theta<1$ which is preferred by all three groups. Now assume that $0^{\circ}<\theta^{*}<1$. Because $\theta^{*}$ is not a local maximum for any of the 1's, elther a small decrease or increase in $\theta$ mugt 1 ncrease uttlity for at least two of the groups, which is sufficient to rule out $\theta^{*}$ as a majority voting equilibrium. 11

Th1s theorem eatablishes that the potential majority voting equilibria al 1 le in the set $\left\{0, \hat{\theta}_{2}, \hat{\theta}_{3}, 1\right\}$. This set can be further reduced, however, by noting that an Implication of Proposition 1 is that both groups two and three strictly prefer a tex rate of zero to a tax rate of $\hat{\theta}_{2}$ (for $\hat{\theta}_{2}$ not equal to zero). This follows directly from the fact thet at $\hat{\theta}_{2}$ both groups two and three pay taxes but do not receive an education. This leaves $\left\{0, \hat{\theta}_{3}, 1\right\}$ as the 
only equtlibrium candldates. In particular, there is only one possible interlor equilibrium. 10

The preceding propositions and theorem allow us to construgt Table 1 , which characterlzes the equilibria that can result ag a function of the values of the parameters of the economy.

As can be seen readily from Table 1 , there are several cases where a majority voting equilibrium does not exist. In the present context this is perhaps not too surprlsing. Proposition 1 implies that preferences are typlcally not single peaked and, as is well known, in this case a majority voting equilibrium may fail to exist. 11

The fact that preferences are not single peaked is due entrely to the discrete nature of the education declsion. Although the resulting non-existence of equllibrium is unattractlve, we belleve that discreteness is 1nherent to the formulation of the question wo study and not a feature to be assuned aray. The resulting problem of non-existence has been dealt with by the majority voting literature in two related but distinct ways. One has been to impose a greater institutional structure on the collective cholce mechanlsm than is implicit in the majorlty voting concept (see e.g. Shepsle and Welngast (1987)). The other is to propose criteria for what constitutes a "reasonable" set of outcomes without specifying particular rules to pick out one or nore of the elements of this set (see, for example, the concept of uncovered set in KeKelvey (1986) and MiIler (1980)). Given the complexity and

${ }^{10}$ The existence of a sole interior equilibrium is an artifact of the three income group distribution; an entire range of lnterlor equilibria can be obtalned in the case of many discrete income groups.

11 For an exarple In Table 1 see case $3 \mathrm{Aa}$. Given the proflle of preferred tax mates $\left(\hat{\theta}_{2}, \hat{\theta}_{3}, 0\right), \hat{\theta}_{2}$ beats $\hat{\theta}_{3}, 0$ beats $\hat{\theta}_{2}$, and $\hat{\theta}_{3}$ beats 0 . 
diversity of the institutions involved in the educational system, and the potentlal arbitrarlnegs of any particular set of rules to plck an equilibrium, our digcuesion will focus on the implications of majority voting for resolution of the educational subsidy problem. These outcomes provide $B$ benchmark agalngt whlch other procedural outcomeg can be compared.

\section{Equllibrlum Outcomes}

Table 1 lists the equllibrlum outcomes for all conflgurations of the parameters describing the economy. This informetion can be used to address two 1ssues. One is to examine how an economy's total income relative to the cost of education affects the cholce of subsidization, holding the $\lambda_{1}$ 's constant. The second is how changes in the distribution of income affect this cholce. Addressing each of these in turn serves as a useful ray to organize the $1 \mathrm{mpl}$ lations of the model.

To examine the relationship between total income and the equilibrium subsidy, consider the patterns that emerge as, we move from panel 1 to panel 4. This movement corresponds to increases in total income relative to the cost of education. In panel 1 the economy is sufficlently poor that even if it devoted all of 1 ts resources to gubgidizing education, at most onty all the rich would be able to attend. Consequently, both group two and three's preferred tax rate is zero which is then the majority voting equilibrium.

In panel 2 the economy is wealthier, although total income does not yet permit any group 3 individual to attend school even were soclety to devote all of 1 ts resources to education. This situation is potentially more intefting than that of panel 1 i 1 t is now economically feasible for the middle class to share in the benefits of taxation. One may, therefore, be inclined to belleve 
that a positive rate of subsidization will be chosen. As Table 1 shows, however, no such majorlty voting equllibrium will energe; the only possible mejority vating equilibrlum is zero. Should $y_{2}$ Individuals desire a positive tax rate, this rate must be strictly greater than $\hat{\theta}_{2}$ since at this rate the middle class is worst off. (At $\hat{\theta}_{2}$ the exploltation of the middle class by the rich is at 1 ts maximum since thls is the largest tax rate compatible with no middle class individual obtaining an education.) But, there is always a lower lax rate (e.g. $\hat{\theta}_{2}$ ltself) which is preferred by both $y_{1}$ and $y_{3}$ since $y_{1}{ }^{\prime} s$ preferred tax rate is $\hat{\theta}_{2}$ and $\mathrm{EU}_{3}$ is monotontcally decreasing on $[0,1]$.

In panel 3 the economy has enough income to send the rich, the middle class, and at least some of the poor to school. In the extreme case it is economically feasible to provide education for all individuals, though this option would exhaust all income. The main feature of the economy is that in equilibrium no group three Individual obtains an education. There are many subcases in panel 3. These correspond to two divislons: (1) whether group two individuais can afford an education independently of the value of the subsidy and (2) whether $y_{1}$ is greater or smaller than $\mu\left(\lambda_{1}+\lambda_{2}\right)$ (for the significance of thls inequality, see Proposition 2). Group two's preferred tax rate is always $\hat{\theta}_{3}$. In $3 A_{\text {, }}$ Hith one possible exception discussed later, whenever an equilbrlum exlsts $1 \mathrm{t}$ is $\hat{\theta}_{3}$ and supported by an alliance of the rich and middle class. The rich switch between $\hat{\theta}_{3}$ and $\hat{\theta}_{2}$, generating en equllibrium of $\hat{\theta}_{3}$ or nonexistence respectively. In $\theta$, the rich prefer elther $\hat{\theta}_{3}$ or zero and, unlike in any of the cases discussed before, an alliance between the rich and poor is feasible. The reason for this allance in case Bb is that there is not enough income to ensure that a sufficlently large number of the poor get educated and the rich are made worse off by any strictly positive tax rate 
(since all revenue must be shared with the middle class and $\left.\mu /\left(\lambda_{1}+\lambda_{2}\right)<y_{1}\right)$. This ylelds zero as the equilibrium.

Panel 4 covers the case of economles with $\mu>E$, l.e., economies with sufflclent income to educate everyone and still have resources left over. There are also many subcases in panel 4. These correspond to the following divisions: (1) whether group two or group three indivtduals can afford an education Independently of the value of the subsidy, (2) whether $y_{1}$ is greater or smaller than $\mu /\left(\lambda_{1}+\lambda_{2}\right)$ and $(3)$ whether the medlan income $\left(y_{2}\right)$ is greater or smaller than the mean. In case $C$ the poor can afford an education independently of any subsidy. Taxation, therefore, is simply a means of redistributing income anong all members of soctety; the barrier to entry aspect no longer plays a role in generating preferences over taxes. The main feature of our model effectively disappenrs: preferences are bingle peaked and the median voter result applies. Consequently the equilibrium tax rate is elther zero or one according to whether $y_{2}$ is greater or smaller than $\mu$. Henceforth our dlscussion will focus on cases $A$ and $B$.

Whenever $\tilde{\theta}_{2}=1$, it is the equllibrium since one 1 always the preferred tax for group 3. Group 2, however, may find it profitable to restrict education to $y_{1}$ and $y_{2}$ individuals (1.e. $\tilde{\theta}_{2}=\hat{\theta}_{3}$ ). If 1 toes. the equllibrium (when it exists) is either $\hat{\theta}_{3}$ or 0 . It $1 \mathrm{~s} \hat{\theta}_{3}$ when the rich and the middle class both find it in their best interests to tax so as to extract as much revenue as possible from $y_{3}$ without allowing the latter to obtain an education.

In panel 4, whenever an equllibrium exists it is the preferred tax rate of the middle class (w1th one exception, discussed later). If $y_{2}<E$ or $\mu>y_{2} \geq E>y_{3}$ and $\mu /\left(\lambda_{1}+\lambda_{2}\right)>y_{1}$ the preferred tax rate of the middle class may be 
elther $\hat{\theta}_{3}$ or 1 . Because these two outcomes have very different 1 mplications for the resulting pattern of educational attainment, 1 is of 1nterest to ask what factors influence the value of $\tilde{\theta}_{2}$ in these cases. We can express the difference between the two levels of utillty as:

$$
\mathrm{EU}_{2}(1)-E \mathrm{U}_{2}\left(\hat{\theta}_{3}\right)=\left(\mu-\mathrm{y}_{2}\right)-\left(E-\mathrm{y}_{3}\right)\left(\mu-\left(\lambda_{1}+\lambda_{2}\right) \mathrm{y}_{2}\right) /\left(\mu-\left(\lambda_{1}+\lambda_{2}\right) \mathrm{y}_{3}\right) .
$$

Note first that if $\mu-y_{2}>E-y_{3}$, then $\tilde{\theta}_{2}=1$ since $\left[\mu-\left(\lambda_{1}+\lambda_{2}\right) y_{2}\right] /\left(\mu-\left(\lambda_{1}+\lambda_{2}\right) y_{3}\right]<1$. Simitarly, if $\mu-y_{2}<E-y_{3}$ and $y_{3} \mu>y_{2} E$ then $\tilde{\theta}_{2}=\hat{\theta}_{3}$.

Differentiation and some algebratc manipulation can be used to show the following:

Proposition 3: The difference in expected utilities in (6) is:
(a) decreasing in $E$
(b) increasing in $\lambda_{1}$ holding $\lambda_{3}$ constant
(c) tлсгеasing in $\lambda_{1}$ holding $\lambda_{2}$ constant if $y_{1}>2 y_{3}$
(d) Iлcгеasing in $\lambda_{2}$ holding $\lambda_{1}$ constant if $y_{2}>2 y_{3}$
(e) iлсгеasing in $y_{1}$
(f) 1лcreasing in $y_{3}$
(g) amblguous with respect to $y_{2}$

To provide intultion for some of the results, conslder what happens when the cost of education 1nereases. At a tax rate of 1 , the emount transferred from the rich to the middle class is unchanged (though $E$ has gone up, this is also true at $\hat{\theta}_{3}$. $\hat{\theta}_{3}$, on the other hand, has increased since $y_{3}$ individuals now need a larger subsidy in order to afford an education. This allows $y_{1}$ and $\mathrm{y}_{2}$ individuals to "explolt" $\mathrm{y}_{3}$ individuals more than before since th takes a greater tax rate than previously for $y_{3}$ individuals to be able to afrord an education. Hence, an increase in E makes $\hat{\theta}_{3}$ relatively more attractive than one. 
When the proportion of the population that is rich increases at the expense of the middle class, the economics underlying the relative attract Iveness of 1 veraus $\hat{\theta}_{3}$ is more subtie. The increase in $\mu$ brought on by this change serves to make a tex rate of 1 relatively more attractlve since the net subsidy received by a $y_{2}$ individual is greater than before. The increase in $\mu$ also decreases $\hat{\theta}_{3}$ since, for the same tax rate as before, more revenue 15 generated. Recalling expression (5) it is easy to show that the net subsidy at $\hat{\theta}_{3}$ decreases. These two effects unamblguousiy make one more attractive relative to $\hat{\theta}_{3}$. Similarly, when elther $y_{1}$ or $y_{3}$ increase, $\mu$ increases and $\hat{\theta}_{3}$ falls. Again it can be shown unambiguously that this change relatively favors a tax rate of 1 over a tax rate of $\hat{\theta}_{3}$.

In the preceding discusgion the analysis was restricted to those cases in whlch the equilibrium was the preferred tax rate for two groups. There are four exceptions to this. When $\mu / \lambda_{1}>E \geq \mu\left(\lambda_{1}+\lambda_{2}\right)$ and $y_{1}>E$ (panel 2), then $\tilde{\theta}_{1}=\hat{\theta}_{2}, \tilde{\theta}_{2}=1$, and $\tilde{\theta}_{3}=0$. In thls case an equilibrium may exist at $\theta=0$, the preferred tax rate for a member of group three, since there may not exist any tax rate that both group one and two both prefer to zero; There is no coalition that is able to block $\theta=0$ in favor of some other tax rate. This is also possible in the case $3 A b$ where $y_{1} z \mu /\left(\lambda_{1}+\lambda_{2}\right)>E \geq \mu$, and $y_{2}<E$. Lastly, in cases $3 \mathrm{Bb}$ and $4 \mathrm{Bb} 1 \mathrm{l}$ where $y_{1} z \mu /\left(\lambda_{1}+\lambda_{2}\right)>y_{2}>\mu>D y_{3}$, we have $\tilde{\theta}_{1}=0, \tilde{\theta}_{2}=\dot{\theta}_{3}$, and $\tilde{\theta}_{3}=1$. Zero, group one'g preferred tax rate, cannot be ruled out as an equilibrium.

\section{Discussion}

Heving discussed the outcomes presented in Table 1 in some detail, it is instructive to note some general polnts that arise in the analysis. 
1. There 1s ho simple ranking of preferred tax rates among groups, e.g. It is not the case that the rich are typically for low taxes and the poor for high taxes, as would be the case if individuals voted over pure redistribution schemes rather than the subsidization of education.

2. A najority voting equilibrium in this framework is essentlally a coalition between (at least) two of the three groups. The alliance that emerges 15 a function of the total income in the economy, its distribution, and the cost of education. In the poorest economies (panels 1 and 2 ), the poor and middle ciasses form an alliance. In panel 3 , however, the alifance flrst switches to the rich and middie class but, as the economy becomes even wealthier (3Bb), the rich may form an alliance with the poor. In panei 4 the allances are elther between the middle class and the rich or the middle class and the poor.

3. Although decreases in $E$ never reduce aggregate becond-period income, ut1lity for a particular group may strictly decrease. For example, a decrease In $E$ that results in a change from an equllibrium of zero (in panel 1 or 2 ) to an equilibrikm of $\hat{\theta}_{3}$ in panel 3 makes group three individuais strictiy worse-off. Similarly, if a decrease in E changes the equilibrium from $\hat{\theta}_{3}$ in panel $3 \mathrm{Aa}$ to one in panel $4 \mathrm{~A}$, group 1 can be made strictly worse-off. Note. furthermore, that eçul1brium levels of Indivdual utilities are discontinuous functions of $E$.

4. Clearly, Table 1 11lustrates that income distribution matters. An 1 mportant message that emerges, however, is that the dependence of the eçulibrium rate of subsidization is not $11 \mathrm{kely}$ to be captured by looking at a few stmple statistics describing income distribution, such as the ratio of median to mean income, or the Gini coefficient. The model predicts that the 
relationship between income distribution and subsidization is quite subtle, a conclusion that should be kept in mind in emplrical work.

6. Conclusion

Governmental support for education varies greatly both internationally and across states and localities within the United States. One possible cause of this varlation is the interaction of income distribution and the political system. This paper has explored this hypothesis within a simple setting in which Individuals are able to affect the private cost of education via subgldization. Rather than repeat the findings here, we outline what we belleve to be several important avenues for future research almed at producing models with sufficlent richness to analyze actual data on education funding. First, the cost and quality of education have been taken as exogenous. In reality, the quality of educational systems vary as do thels costs. In the case of hlgher education both affordability and quality are 1mportant attributes of the system. In primary and secondary education, tuttion is typlcally zero and the variation is primarily in qualtty. These features need to be incorporated into the enalysis. The (endogenous) existence of private alternatives is also an Important feature to introduce, since this alternative w1l necegsar1ly affect people's preferences over the allocation of resources to public education. 12 In the case of prinary and secondary education it is also important to develop models in which location is stressed since much of this education is both locally financed and consuned. ${ }^{13}$ Finally, the analysis here has taken place in a static setting. It is also of interest to study

${ }^{12}$ Glomm and Ravikunar (1990) study a model in which purely public and purely private systems are compared.

${ }^{13}$ Recent work along these 1 Ines includes Benabou (1991) and Durlauf (1991). 
dynamic versions of these models that permit one to understand how the educational system and Income distribution w111 evolve over time and the nature of their interactions, 14

${ }^{14}$ Bullding on the ear11er work of Becker and Tomes (1979) and Loury (1981), recent papers by Galor and Zelra (1990) and Ljungqulst (1991) study the evolution of income distribution in dynamic models in whlch credit constraints affect educational attainment. In these models, however, there is no endogenous cholce of polfcy; all features of the educational system are taken to be exogenous. Durlauf (1991) is an exception. 
Table 1 Voting Equilibria

\begin{tabular}{|c|c|c|c|}
\hline Parameter Restrictions & $\tilde{\theta}_{1} \quad \tilde{\theta}_{2}$ & $\tilde{\theta}_{3}$ & Equil l brium \\
\hline 1. $\quad \mu / \lambda_{1} \leq \mathrm{E}$ & 0 & 0 & 0 \\
\hline 2. $\quad \mu / \lambda_{1}>E=\mu\left(\lambda_{1}+\lambda_{2}\right)$ & $\begin{array}{ll}\hat{\theta}_{2} & 0 \\
\hat{\theta}_{2} & 1\end{array}$ & $\begin{array}{l}0 \\
0\end{array}$ & $\begin{array}{c}0 \\
0 \text { or NE }\end{array}$ \\
\hline $\begin{array}{l}\text { b. } y_{1}>\mu /\left(\lambda_{1}+\lambda_{2}\right) \\
\text { B. } y_{2} \geq E \\
\text { a. } y_{1}<\mu /\left(\lambda_{1}+\lambda_{2}\right) \\
\text { b. } y_{1}>\mu /\left(\lambda_{1}+\lambda_{2}\right)\end{array}$ & $\begin{array}{ll}\hat{\theta}_{2} & \hat{\theta}_{3} \\
\hat{\theta}_{3} & \hat{\theta}_{3} \\
\hat{\theta}_{2} & \hat{\theta}_{3} \\
\hat{\theta}_{3} & \hat{\theta}_{3} \\
\hat{\theta}_{2} & \hat{\theta}_{3} \\
\hat{\theta}_{2} & \hat{\theta}_{3} \\
\hat{\theta}_{3} & \hat{\theta}_{3} \\
\hat{\theta}_{3} & \hat{\theta}_{3} \\
0 & \hat{\theta}_{3} \\
0 & \hat{\theta}_{3}\end{array}$ & $\begin{array}{l}0 \\
0 \\
1 \\
1 \\
0 \\
1\end{array}$ & $\begin{array}{l}\text { NE } \\
\hat{\theta}_{3} \\
\mathrm{NE} \\
\hat{\theta}_{3} \\
\mathrm{O} \text { or } \mathrm{NE} \\
\mathrm{NE} \\
\hat{\theta}_{3} \\
\hat{\theta}_{3} \\
\mathrm{O} \\
0 \text { or NE }\end{array}$ \\
\hline
\end{tabular}


4. $\mu>E$
A. $y_{2}<E$

B. $y_{2} \geq E y_{3}<E$

a. $y_{1}<\mu /\left(\lambda_{1}+\lambda_{2}\right)$

1. $y_{2}<\mu$

11. $y_{2} z \mu$

b. $y_{1}>1 /\left(\lambda_{1}+\lambda_{2}\right)$

I. $y_{2}<\mu$

11. $y_{2}^{z \mu}$

c. $y_{3} z E$

a. $y_{2}>\mu$
b. $y_{2}<\mu$

\begin{tabular}{lll|l}
$\hat{\theta}_{2}$ & 1 & 1 & 1 \\
$\hat{\theta}_{3}$ & 1 & 1 & 1 \\
$\hat{\theta}_{2}$ & $\hat{\theta}_{3}$ & 1 & NE \\
$\hat{\theta}_{3}$ & $\hat{\theta}_{3}$ & 1 & $\dot{\theta}_{3}$
\end{tabular}

$\hat{\theta}_{3} \quad \hat{\theta}_{3}$

$\hat{\theta}_{3} 1$

$\hat{\theta}_{3} \hat{\theta}_{3}$ :

$\theta_{3}$

1

$\tilde{\theta}_{3}$

NE

1

O or NE

0

1 


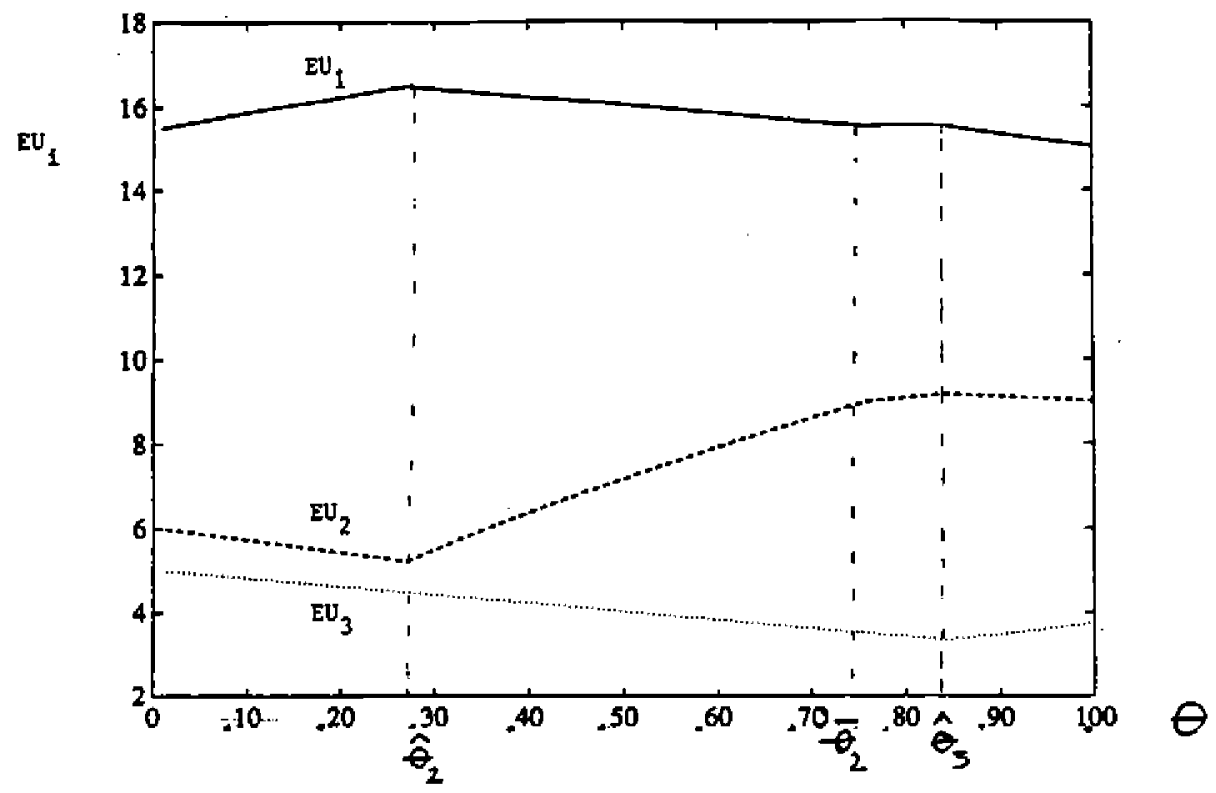

FIGURE ONE 
Ales1na, A., "Macrocconomlo Pollcy in a Two Party Systen as a Repeated Came," Quarterly Journel of Econonics 102 (1987):651-678.

Becker, G., and Tomes, N., "An Equlilbrium Theory of the Distribution of Income and Intergenerational Mob1lity," Journal of Political Economy 87 (1979), $1153-1189$.

Behrman, J., Follak, R., and Taubman, P., "Fanlly Resources, Famlly S1ze, and Access to Financing for College Education, Journal of Political Economy 97 (1989): $398-419$.

Benabol, R., "Locetion, Production, and Education: The Workings of a City," ml meo, MIT 1991.

Buchanan, J., and Tullock, G. The Calculus of Consent. Ann Arbor, 1962.

Creedy J., and Francols, P., "Financing Higher Education and Majority Voting," Journal of Public Economics 43 (1990), 181-200.

Downs, A. An Economic Theory of Democrecy. Neн York, 1957

Durlauf, S., "Persistent Income Inequal1ty I: Human Cap1tel Formation and the Emergence of Poverty," mimeo, Stanford, 1991.

Fernandez, R, and Rodrik, D., "Resistance to Reform: Status Quo Bias in the Presence of Individual-Specific Uncertainty, " forthcoming, Anerican

Economic Review (1991).

Galor, 0 . and Zelra, J, "Income Distribution and Macroeconomics", tnimeo Brown University, 1590 .

Glomm, G., and Rayikumar, B., "Public vs. Private Investment in Human Capltal: Endogenous Growth and Income Inequality, " mimeo, V1rginla, 1990

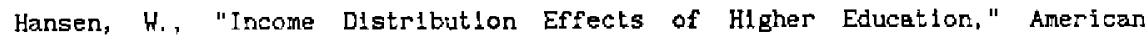
Economic Review (1971): 335-340.

Hansen, W. Lee, and Heisbrod, Burton. Beneflts, Costs and Finance of Higher Education. Chicago: Markham, 1969.

Johnson, C., "Subsidies for Higher Education," Journal of Labor Economics 2 [1984): $303-318$.

Lommerud, K., "Educational Subsidies then Peletive Income Matters," Oxford Economic Papers 41 (1989): 640-652.

Lott, \., "An Explanation for Public Provision of Schooling: The Importance of indoctrination," JournaI of Law and Economles 33 (1990): 199-231.

Loury, G. " "Intergenerational Transfers and the Distribution of Earnings," 
Econometrica 49 (1981), 843-867.

Ljungqvist, L., "Economic Underdevelopment: The Case of a Missing Market for Human Capltal, " m1meo. Madison, 1991.

McKelvey, R., "Covering, Dominance, and Institution Free Properties of Soclal Cholce," Amerlcan Political Sclence Review, 1986: 284-314.

Meltzer, A. and Richard, S., "A Ratlonal Theory of the Slze of Coversment," Journal of Polltical Economy Bg (1981): 914-927.

Miller, N., "A New Solution Set for Tournamenta and Kajority Voting," American Political Sclence Review, 1980: 68-96.

Peltzman, S., "The Effect of Government Subsidies in Kind on Private Expenditure: The Case of H1gher Education," Journal of Polltical Economy 81 (1973): $1-27$.

Perott1, R., "Polltical Equilibrium, Incone Dlstribution and Growth," mimeo, MIT, 1990 .

Persson, T. and Tabelilnt, G., "Is Inequallty Harmful for Growth? Theory and Evidence, " mimeo, Berkeley, 1990.

Schumpeter, J., Capltal1sm, Soclal1sm, and Democracy. New York, 1947.

Shepsle, K., and Helngast, B. , "Institutional Foundations of Comittee Power," American Polltical Sclence Revieh 81 (1987), 85-104.

Stiglitz, J, "The Demand for F,ducation in Public and Private School Systems," Journal of Public Economics 3 (1974): 349-385. 